\title{
Implementation of Specific Neurosurgical Protocol for Urgent Elective and Emergency Patients during the COVID-19 Pandemic in Croatia: Institutional Experience
}

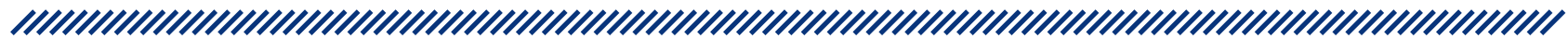

${ }^{1-4}$ Bruno Splavski

${ }^{1-3}$ Krešimir Rotim

1,2 Mia Jurilj

1,2 Tomislav Sajko

1 Department of Neurosurgery, Sestre milosrdnice University Hospital Center, Zagreb, Croatia

2 University of Applied Health Sciences, Zagreb, Croatia

3 J. J. Strossmayer University Faculty of Medicine, Osijek, Croatia

4 J. J. Strossmayer University Faculty of Dental Medicine and Health, Osijek, Croatia

\section{Abstract}

Introduction: The COVID-19 pandemic was declared on January 30, 2020. The disease has rapidly disseminated throughout Europe, reaching Croatia from late February onward, representing a great burden to the national health care system. Our institution's capacity for emergency neurosurgery was adjusted to assure adequate degree of protection for both the patients and medical workforce. Separate COVID-19-free pathways were ensured, while regular operative program has been attuned to the existing epidemiological condition.

Aim: To explain the implementation of neurosurgical protocol for urgent elective and emergency traumatic brain injury patients during the COVID-19 pandemic based on our institutional experience.

Methods: The time of pandemic was divided into 3 separate two-month periods. Patients, who suffered a traumatic brain injury and were not tested for corona virus, were considered COVID positive and were included in the analysis investigating the type and severity of inju- ry, period of hospital admission and surgery, methods of surgery, and outcome.

Results: A series consisted of 16 patients who were tested for COVID-19 at hospital admission, and underwent urgent/emergency surgery before the test results became known. Surgery was performed according to the specifically designed operative COVID-19 protocol. Skull fracture and traumatic intracranial hemorrhage were mainly observed. Moderate injury was recorded less frequently, particularly during the lockdown, and post-lockdown summer. The majority of patients recuperated well, having good recovery.

Conclusion: A specific operative protocol, employment of protective measures, and a separate operating theatre are mandatory for a safe and successful management of traumatic brain injury to evade transmission of the infection.

Keywords: COVID-19, traumatic brain injury, operative protocol, protective measures

Article received: 01.12.2020.

Article accepted: 15.01.2021.

https://doi.org/10.24141/1/7/1/1

Corresponding author:

Bruno Splavski

A: Department of Neurosurgery, Sestre milosrdnice University Hospital Center, Vinogradska c. 29, 10000 Zagreb, Croatia

E-mail: splavuno@gmail.com

$\mathrm{T}:+38513787111$ 


\section{Introduction}

World Health Organization (WHO) declared the COVID-19 pandemic on January 30, 2020 in order to contain the spread of the disease worldwide ${ }^{1}$. However, the disease has rapidly disseminated throughout Europe from late February 2020 onward, and the first COVID-19 patient in Croatia was identified on February 25, 2020. By the end of November 2020, the number of daily-infected people in Croatia has reached approximatively 4,000, representing a great burden to the national health care system.

Nevertheless, Croatian health system soon became adjusted to handle this pandemic appropriately and to avoid probable risks of failure, particularly in an emergency.

The capacity for emergency neurosurgery of the Department of Neurosurgery of Sestre milosrdnice University Hospital Center in Zagreb, Croatia, was reinforced. Accordingly, separate COVID-19-free pathways for emergency and elective neurosurgical patients were ensured, while regular operative program has been attuned to the existing epidemiological condition, not affecting standard neurosurgical care at all, but assuring an adequate degree of protection for both the patients and medical workforce ${ }^{2-4}$.

In compliance with national public-health recommendations and epidemiologists' instructions for patients with stable health condition, elective oncological and vascular patients were operated on continuously in separate operative theaters, while spinal degenerative disease patients were mostly postponed for a few weeks if not being urgent elective. Hence, traumatic brain injury (TBI) patients remained the most endangered group commonly affected by COVID-19 condition, which only aggravated such an injury as the largest contributor to trauma-related mortality ${ }^{5}$.

Both conditions appeared to be especially precarious in the elderly, who are often receiving oral anticoagulation therapy ${ }^{6}$, and where a peak TBI incidence was seen predominantly?. Therefore, TBI constitutes a major health, socioeconomic, and epidemiological problem ${ }^{8}$, which may only be compared to the one brought by recent COVID-19 pandemic, since both groups of patients are competing for the admission to critical care units ${ }^{1}$.

The aim of this paper was to explain the implementation of neurosurgical protocol for urgent elective and emergency TBI patients during the COVID-19 pandemic in Croatia, based on our institutional experience.
This protocol was designed to optimize neurosurgical care under specific conditions, to prevent the dissemination of the disease, as well as to minimize the risk of the disease transmission among neurosurgical patients and medical personnel as much as possible.

\section{Materials and Methods}

The time of pandemic was divided into 3 separate twomonth periods, between the beginning of March and the end of August 2020.

The first period was that of the epidemiological strict lockdown due to the outbreak of the disease (March to April), the second one was an immediate post-lockdown period, when restrictive epidemiological measures became less firm (May to June), and the last one was the summer post-lockdown period, where measures continued to be relaxed and the pandemic began to slow down. (July to August).

All neurosurgical patients who suffered a TBI and were not tested for corona virus, were considered COVID positive at hospital admission and were included in the analysis.

Informed consent was obtained from every patient enrolled, and the local ethics committee approved the study.

The TBI patients who were admitted to hospital, but were not operated on, were excluded from the analysis.

In line with a specifically designed operative protocol, every TBI patient who arrived from an outward hospital/ institution without having a nasopharyngeal swab (NS) test was considered COVID-19 positive and was surgically treated according to the COVID-19 operative protocol due to an emergency, prior to receiving the NS test results.

Postoperatively, most patients were mechanically ventilated and kept at the Intensive Care Unit (ICU) for a short period. Afterwards, all were accommodated in appropriate separate wards to minimize cross infection. They were all screened for the disease if any COVID-19 symptom was suspected following surgery.

The medical staff involved were provided with personal protective equipment (PPE) in separate operating 
theater ${ }^{4}$. However, NS testing was performed on symptomatic neurosurgical stuff only.

The investigative parameters were as follows: type of injury, severity of injury, period of hospital admission and surgery, method of surgery, and outcome at discharge.

Glasgow Outcome Score (GCS) assessed the severity of injury ${ }^{9}$, while Glasgow Outcome Scale Extended (GOSE) measured the outcome ${ }^{10}$.

\section{Results}

During the entire period (from March 1, until August 31, 2020), 16 urgent elective and/or emergency neurosurgical TBI patients were operated on.

A series consisted of 12 males and 4 females - their mean age was 65.8 years. The oldest patient was an 88 -yearold male, while the youngest was a 29-year-old man.

All were tested for COVID-19 at hospital admission, and underwent urgent/emergency surgery before the test results became known. Surgery was performed according to the specifically designed operative protocol for COVID-19 positive or corona suspected patients. None of them had a positive result.

A skull fracture and traumatic intracranial hemorrhage were mainly observed, including acute epidural, and subdural hematoma, intracerebral hematoma, posttraumatic subarachnoid hemorrhage, as well as chronic subdural hematoma/hygroma. (Figure 1)

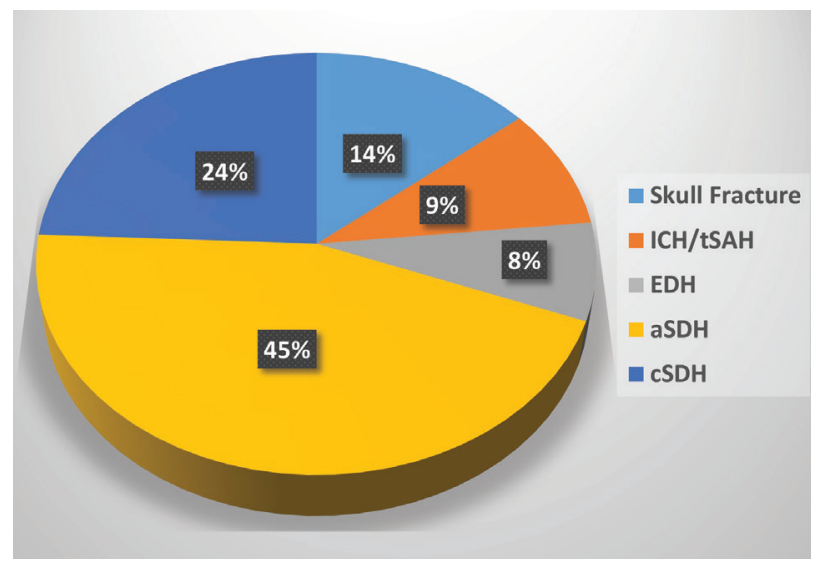

Figure 1. Division of TBI according to injury type
Considering the severity of TBI, moderate injury was observed less frequently, particularly during the lockdown, and post-lockdown summer period. (Figure 2)

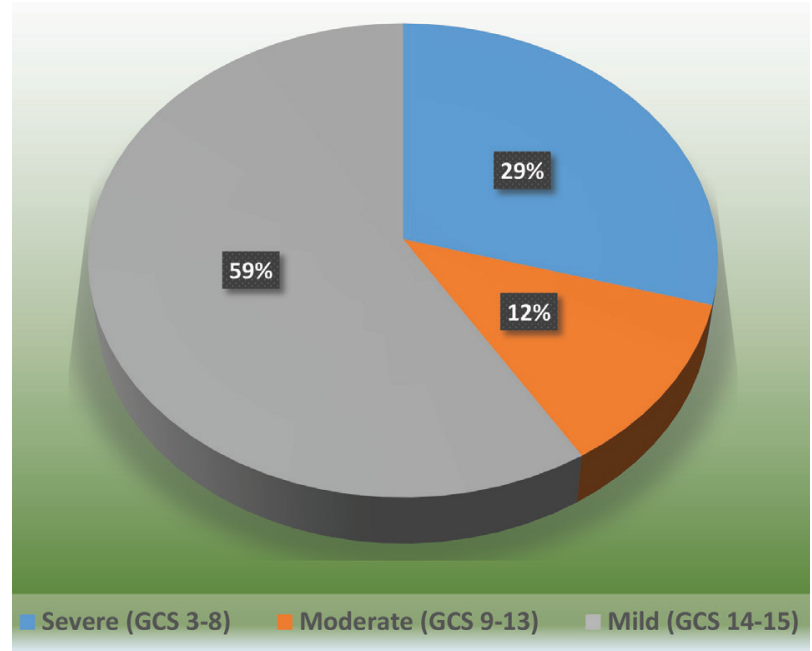

\section{Figure 2. Division of TBI according to severity of injury}

All patients underwent a decompressive unilateral craniectomy, except 3 patients with chronic subdural hematoma/hygroma, where cranial trepanation was carried on, and 2 patients with intracerebral hematoma, where external ventriculostomy was only performed. (Figure 3)

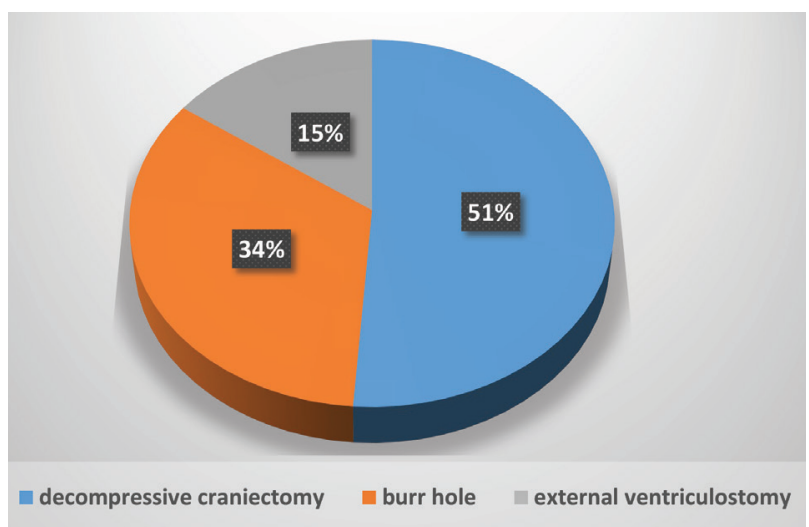

\section{Figure 3. Division of TBI according to type of surgery performed}

A postoperative examination of possible complications observed in COVID-19 positive/suspected patients undergoing neurosurgery was done. Such complications were divided into thrombotic, hemorrhagic, pulmonary, cardiac, neurological, and local ${ }^{11}$. 
No immediate postoperative complications related to the surgical procedure were recorded in our series.

None of the patients died, and the majority (57\%) recuperated well, having good recovery. (Figure 4)

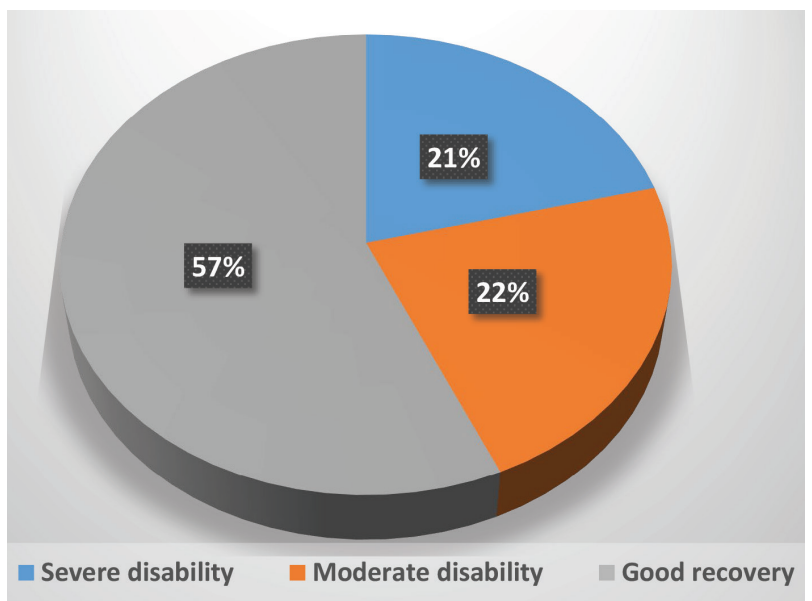

Figure 4. Division of patients according to outcome at hospital discharge

\section{Discussion}

A year ago (December, 2019), an outbreak of pneumonia of unknown cause was linked to a seafood market in Wuhan, China, and previously unknown coronavirus referred to as COVID-19 was discovered ${ }^{12}$. From that time on, the disease has disseminated all over the world rapidly.

An early response to the COVID-19 outbreak by the neurosurgical community has followed, creating a mounting evidence of scientific documents aiming to update neurosurgical practice concerned with this entirely new condition ${ }^{13}$. The main concern was to ensure the principles of safety of the surgical teams caring for COVID-19 patients, which appeared to be crucial to prevent the spread of infection among patients and within hospitals ${ }^{3}$. Consequently, elective surgeries were markedly reduced globally, mainly allowing surgeons to perform urgent elective and emergency procedures only ${ }^{14}$. Accordingly, a number of criteria for time-managing neurosurgical procedures that cannot be postponed were initiated ${ }^{15,16}$, imposing rearranging and reduction of many neurosurgical activities ${ }^{17}$.

Herein, we present our institutional experience in implementing national public-health recommendations, and in producing specifically designed operative protocol for COVID positive and COVID suspected urgent elective and emergency neurosurgical TBI patients.

A separate operative theatre has been created for the management of high-risk/high-complexity patients who may have been exposed to COVID-19, including those who suffered a TBI. For these patients, careful clinical prioritizing was assured to select them for surgery, and to maintain social distancing. The methods to decrease the risk of the infection transmission and to enable medical staff safety included regular PPE supply/utilization, and consistent NS testing of all patients and medical stuff involved. Nonetheless, NS testing was performed on symptomatic neurosurgical stuff only. Other authors have also confirmed that monitoring healthcare workers and patients, and separating infected patients in dedicated wards may considerably reduce the risk of infection ${ }^{17}$.

Executing such a protocol, we have managed to contain the spread of the disease throughout the hospital system, and to protect our patients and stuff from cross infection, since none of the TBI patients from this series, as well as none of the personnel involved has contracted the disease during the analyzed period. In addition, the substantial majority of patients recuperated well, having good recovery.

A small but sufficient group of clinicians and neurosurgeons responsible for decision-making was convened to supervise newly created protocol delivery, to consider whether elective surgery patients would need access to ICU and to ensure a sufficient amount of free ventilators for COVID-19 positive TBI patients. This was proved essential for the implementation of a comprehensive and effective approach to urgent elective and emergency COVID-19 positive and/or suspected TBI neurosurgical patients.

Although the rate of postoperative complications, including pulmonary disorder, are knowingly more frequent in patients with COVID-19 when compared to regular surgical patients ${ }^{11}$, we did not record any of these in our small sample.

Considering our experience, it seems that COVID-19 pandemic affected many aspects of standard neurosurgical care of TBI patients and their selection for surgery. The employment of protective measures appears to be crucial for the disease dissemination containment. However, such measures required for the personnel may decrease an acceptable field of view under the surgical microscope, which is the essential ingredient of a safe surgery ${ }^{18}$. 


\section{Conclusion}

A well-made specific protocol, the employment of protective measures, and a separate operating theatre are mandatory for a safe and successful management of TBI patients to evade the transmission of the infection during COVID-19 pandemic.

Further assessment of COVID-19 operative neurosurgical protocol is needed to upgrade the existing international and national public-health recommendations.

\section{References}

1. Wax RS, Christian MD. Practical recommendations for critical care and anesthesiology teams caring for novel coronavirus (2019-nCoV) patients. Can J Anaesth. 2020; 67(5):568-76. doi: 10.1007/s12630-020-01591-x.

2. Grelat M, Pommier B, Portet S, Amelot A, Barrey C, Leroy HA, Madkouri R. Patients with Coronavirus 2019 (COVID-19) and surgery: Guidelines and checklist proposal. World Neurosurg 2020; 139:e769-e773. doi: 10.1016/j. wneu.2020.04.155.

3. Oh D, Kang YM, Choi JY, Lee WJ. What surgeons should know about emergency operation for COVID-19 confirmed patients: A case report. Int J Surg Case Rep. 2020; 77:503-6. doi: 10.1016/j.ijscr.2020.10.137.

4. Ti LK, Ang LS, Foong TW. Ng BSW. What we do when a COVID-19 patient needs an operation: operating room preparation and guidance. Can J Anaesth 2020; 67(6):756-8. doi: 10.1007/s12630-020-01617-4.

5. Rubiano AM, Carney N, Chesnut R, Puyana JC. Global neurotrauma research challenges and opportunities. Nature 2015; 527(7578):S193-7.

6. Iaccarino C, Carretta A, Nicolosi F, Morselli C. Epidemiology of severe traumatic brain injury. J Neurosurg Sci 2018; 62(5):535-41.
7. Peeters W, van den Brande R, Polinder S, Brazinova A, Steyerberg EW, Lingsma HF, et al. Epidemiology of traumatic brain injury in Europe. Acta Neurochir. 2015; 157(10):168396. doi: 10.1007/s00701-015-2512-7.

8. Ghajar J. Traumatic brain injury. Lancet 2000;356(9233):9239. doi :10.1016/S0140-6736(00)02689-1.

9. Doglietto F, Vezzoli M, Gheza F, Lussardi GL, Domenicucci $M$, Vecchiarelli L, et al. Factors associated with surgical mortality and complications among patients with and without coronavirus disease 2019 (COVID-19) in Italy. JAMA Surg 2020; 155(8):691-702. doi:10.1001/jamasurg.2020.2713.

10. Teasdale G, Jennett B. Assessment of coma and impaired consciousness: a practical scale. Lancet 1974; 2:81-4.

11. Wilson JTL, Pettigrew LEL, Teasdale GM. Structured interviews for the Glasgow Outcome Scale and the Extended Glasgow Outcome Scale: Guidelines for their use. J Neurotrauma 1997; 15(8):573-85.

12. Zhu N., Zhang D., Wang W. Li X, Yang B, Song J, et al. A novel coronavirus from patients with pneumonia in China, 2019. N Engl J Med 2020; 382(8):727-33. doi: 10.1056/ NEJMoa2001017.

13. Germanò A, Raffa G, Angileri FF, Cardali SM, Tomasello F. Coronavirus disease 2019 (COVID-19) and neurosurgery: literature and neurosurgical societies recommendations update. World Neurosurg. 2020; 139:e812-e817. doi: 10.1016/j.wneu.2020.04.181.

14. Fontanella MM, De Maria L, Zanin L, Neurosurgical practice during the severe acute respiratory syndrome coronavirus 2 (SARS-CoV-2) pandemic: a worldwide survey. World Neurosurg. 2020; 139:e818-e826.

15. Agosti E, Giorgianni A, Pradella R, Locatelli D. Coronavirus disease2019(COVID-19) outbreak:single-centerexperience in neurosurgical and neuroradiologic emergency network tailoring. World Neurosurg 2020; 138:548-50.

16. Zoia C, Bongetta D, Veiceschi P. Neurosurgery during the COVID-19 pandemic: update from Lombardy, northern Italy. Acta Neurochir (Wien) 2020; 162(6):1221-22.

17. Raneri F, Rustemi O, Zambon G, Del Moro G, Magrini S, Ceccaroni Y, et al. Neurosurgery in times of a pandemic: a survey of neurosurgical services during the COVID-19 outbreak in the Veneto region in Italy. Neurosurg Focus 2020; 49(6):E9.

18. Celtikci E, Karaaslan B, Börcek AO, Emmez OH. Reduced field of view under the surgical microscope due to personal protective equipment: lessons learned during the COVID-19 pandemic. Neurosurg Focus 2020; 49(6):E15. 


\section{PROVEDBA SPECIFIČNOGA NEUROKIRURŠKOG OPERACIJSKOG POSTUPNIKA U HITNIH ELEKTIVNIH I HITNIH BOLESNIKA TIJEKOM PANDEMIJE BOLESTI COVID-19 U HRVATSKOJ: INSTITUCIJSKO ISKUSTVO}

1-4 Bruno Splavski

${ }^{1-3}$ Krešimir Rotim

1,2 Mia Jurilj

1,2 Tomislav Sajko

1 Klinika za neurokirurgiju KBC „Sestre milosrdnice“, Zagreb, Hrvatska

2 Zdravstveno veleučilište Zagreb, Zagreb, Hrvatska

3 Medicinski fakultet, Sveučilište J. J. Strossmayer u Osijeku, Osijek, Hrvatska

4 Fakultet za dentalnu medicinu i zdravstvo, Sveučilište J. J. Strossmayer u Osijeku, Osijek, Hrvatska

\section{Sažetak}

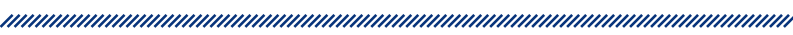

Uvod: Pandemija bolesti COVID-19 proglašena je 30. siječnja 2020. Bolest se brzo proširila diljem Europe stigavši u Hrvatsku krajem veljače, što je predstavljalo veliko opterećenje nacionalnom zdravstvenom sustavu. Mogućnosti naše ustanove za pružanje hitnih neurokirurških usluga prilagođene su tako da osiguraju dostatan i podjednak stupanj zaštite bolesnika i medicinskog osoblja. Osigurani su nekontaminirani smještajni kapaciteti za COVID negativne bolesnike, a redoviti operacijski program prilagođen je trenutačnoj epidemiološkoj situaciji.

Cilj: Na temelju našeg stečenog iskustva, objasniti primjenu neurokirurškoga operacijskog postupnika u hitnih elektivnih i hitnih bolesnika s traumatskom ozljedom mozga za tijekom pandemije bolesti COVID-19.
Metode: Vrijeme trajanja pandemije podijeljeno je u tri dvomjesečna razdoblja. U istraživanje su uključeni oni bolesnici s traumatskom ozljedom mozga koji nisu bili testirani na koronavirus, pa su time smatrani COVID pozitivnima. Analizirani su sljedeći pokazatelji: vrsta i težina ozljede, razdoblje u kojem je bolesnik primljen u bolnicu i operiran te način i ishod kirurškog liječenja.

Rezultati: Istraživanu skupinu činilo je 16 kirurški liječenih bolesnika testiranih na COVID-19 pri bolničkom primitku, koji su hitno operirani u skladu s posebno oblikovanim operacijskim postupnikom za COVID-19 prije nego što su rezultati testiranja postali poznati. Najčešće zabilježene vrste ozljede bile su prijelom lubanje i intrakranijsko krvarenje. Umjerena ozljeda mozga bila je po težini najmanje zastupljeni oblik ozljede, posebice za vrijeme trajanja zatvaranja i tijekom ljeta. U većine bolesnika zabilježen je dobar oporavak.

Zaključak: Poseban operacijski postupnik, kao i primjena zaštitnih mjera u odvojenim operacijskim dvoranama, uvjet su sigurnog i uspješnog liječenja bolesnika s traumatskom ozljedom mozga kako bi se spriječilo širenje infekcije.

Ključne riječi: COVID-19, traumatska ozljeda mozga, operacijski postupnik, zaštitne mjere 